\title{
Conflict between the Accounting Act and Czech Accounting Standards in land
}

\author{
Kristina Kabourkova ${ }^{1, *}$ \\ ${ }^{1}$ Institute of Technology and Business, School of Expertness and Valuation, Okruzni 517/10, 37001 \\ Ceske Budejovice, Czech Republic
}

\begin{abstract}
The paper deals with the analysis of existing Czech accounting procedures in the case of land accounting. The method of process analysis is used, where the currently valid methodological procedures are examined. The strengths and weaknesses of this methodology are defined. It is found that the accounting and valuation of land according to Czech Accounting Standards is in conflict with the Accounting Act, according to which accounting data should provide a true picture of the status and value of the entity's assets. The purchase price of the land is entered into bookkeeping and any decrease or increase in value is never accounted for again. In the case of forest land, the value of the land and the value of the plants grown on it are not accounted for separately. The accounting therefore does not provide users with true and current information. The good thing is that these accounting policies do not burden the accounting entity in any way. Furthermore, a proposal for new methodological procedures is presented. According to them, it would be possible to update the accounting data depending on the condition of the land and the development of market prices. Based on an expert opinion, a significant increase or decrease in the current value of the land would be accounted for. In the case of a forest, it would be possible to use analytical accounts to account separately for the condition of the land and the condition of the forest foliage. These new procedures would make it possible to reflect in bookkeeping the actual state of the entity's assets. However, the disadvantage is the higher financial and time demand. Subsequently, the advantages and disadvantages of the currently effective and proposed methodology are compared.
\end{abstract}

Keywords: accounting procedures, valuation of land, market price, enterprise's assets, tangible fixed assets

\section{Introduction}

The issue of accounting for land that is not a commodity is not addressed very often in literature. This is probably, among other things, because economic theory considers land to be a fixed factor of production that is not consumed. Nevertheless, valuation practice shows that the price of land changes over time. However, land accounting is a relatively important issue, as the price of land can in some cases be an important item in deciding how to deal with it.

\footnotetext{
*Corresponding author: kabourkova@mail.vstecb.cz
} 
In the Czech Accounting Standards, which currently regulate accounting in the Czech Republic, land is considered as tangible fixed assets that do not depreciate. It is based on the opinion that the value of land does not change over the years or, on the contrary, increases. According to Czech accounting regulations, the increase in the price of land cannot be accounted for. The author believes that this rule in some cases makes it impossible to show the actual value of land. This is, for example, a plot of land on which there is a forest. It is not accounted for separately, as the forest is considered to be a part of the land. However, as the forest grows, so does the amount of wood and other forest functions also improve. The value of this land is objectively increasing. However, this fact will not be reflected in Czech accounting.

The opposite example can be a decrease in the value of land. If the land is contaminated, its value will be drastically reduced. In the case of successful reclamation of such land, allowances can be accounted for, which are used in the event of a temporary decrease in the value of the property and when the value is expected to increase back to the original level. After successful reclamation, allowances will be cancelled.

The situation is more complicated if reclamation does not take place at all or if a complete repair is not possible. In such a case, there is a permanent decrease in the value of the land, which is not reflected in the accounting at all. The land is still registered at its original value. The consequence is again the fact that the book value of the land has been distorted and the accounting does not show this fact. This creates a conflict with the basic principles of accounting, which then do not fulfil one of its important tasks.

It can be assumed that the value of land will increase in the future. For this reason, it is necessary to pay attention to the valuation of land and the accounting presentation of changes that have resulted in a change in their true value.

The aim of the article is to analyse those land accounting procedures that currently apply according to Czech Accounting Standards. In the next part, such a solution will be proposed, the result of which will be an accurate representation of reality.

The following research questions are asked in this paper:

1. Is the current land accounting procedure according to Czech Accounting Standards in accordance with the Accounting Act?

2. Is there a method of accounting for land that corresponds to the principle of actual representation of reality?

\section{Literature review}

Fixed assets are an essential part of an entity's assets. Hence the need to deal with them efficiently and to account for it properly.

Kouřilová [1] states that accounting is currently in the dimension of data manipulation. This can only be agreed with, as the overestimation and the method of said overestimation of certain components of assets, especially fixed assets, can be done on purpose.

The efficiency of the organization's activities is determined by the level of securing fixed tangible assets and their rational use in economic processes [2]. This is mainly because tangible fixed assets are effective in the basic activities of the company and are of special importance [3].

Land is an important part of fixed assets. It is an asset still undervalued in the Czech Republic, mainly due to the functions that the land performs and because the area of land is limited and in our conditions it is not possible to increase the area of the country (e.g. by building islands in the sea).

At present, we see the consequences of poor land management, when it was and still is being occupied due to construction, although it is possible to rebuild old unused areas instead. It is always cheaper for the investor to build and thus destroy a meadow or field forever, but 
it is extremely expensive for society as a whole. Unfortunately, politicians who decide on territorial plans are not aware of this and are preparing big problems for future generations with their short-sighted decisions. Already today, many smaller municipalities have major problems with the lack of water, which due to the massive development cannot be absorbed into the soil, but completely unnecessarily drained by streams and rivers out of our country. Other problems, such as agricultural drought, etc., are also associated with poor soil management.

The land is multifunctional because it can serve simultaneously or consecutively for different purposes [4]. It can therefore be stated that land is a special type of property and with regard to its irreplaceability, it is necessary to handle it with the care of a proper manager.

If the land owned by a company is intended for long-term use, for capital appreciation or for obtaining revenue, we classify it as tangible fixed assets. It is included in the balance sheet in assets, used for more than one year and the valuation amount is determined by the accounting entity. It gradually wears out, its value transforms into costs in the form of amortization [5].

Land values are often close to or even higher than building values [6]. It can be expected that the value of land in the world will increase significantly in the future, as its area is limited and with the growing population of the Earth and with increasing needs, there will be an increasing hunger for land. There is already a large trend in investing in land [7].

Investments in real estate development are riskier than investments in stabilized real estate assets. The Development Assets Value Index (DAVI) reveals the behavior of developers and landowners using the options contained in land ownership [8].

Land ownership and accounting is regulated in the Czech Republic by a number of legal norms. They are characterized by legal data (e.g. ownership rights, land decisions), technical parameters (e.g. availability, capacity of utilities), other parameters (e.g. buildability, size) [9].

According to the Cadastral Act No. 256/2013, land is understood as a part of the earth's surface separated from neighbouring parts by the boundary of a territorial unit or the boundary of a cadastral territory, the boundary of ownership, the boundary determined by a regulatory or territorial plan, etc.

Accounting based on Decree 500/2002 Section 7 considers land as fixed assets.

The indicative chart of accounts classifies land to account 031 land. This account records land that is a tangible fixed asset from the point of view of the accountant, always regardless of the amount of valuation, as long as it is not a business commodity. The valuation of the land includes forest vegetation or planted trees and shrubs unless they are considered cultivational units of permanent crops. Land does not depreciate. This account does not include parts of the land that are depreciated and reported as assets or parts thereof in the accounts of buildings, etc.

Land (like all other assets and liabilities) is valued at historical prices in our country, which means that it is valued at the price that was spent on its acquisition. This price refers to the time of acquisition [10].

According to the Czech Accounting Standard No. 013, technical improvement is not accounted for in the case of cultivational units of permanent crops, adult and labour animals and assets in account group 03 - tangible fixed assets not depreciated. However, this is a shortcoming, as in many cases the value of the relevant assets may increase.

Technical improvements can be made to the land. This can occur, for example, as a result of landscaping, when the appearance of the environment or water drainage conditions change significantly. Accessories that are not legally considered a building by the Building Act, such as ground tiles and stones that are not an integral part of the land, may also be added to the 
land. However, the installation of these utilities cannot increase the value of the land, because it is a separate tangible fixed asset [11].

The current legal regulation of land accounting shows that in many cases the book value of land in the Czech Republic is underestimated, as its actual value increases over time. These are mainly forest lands, which are valued according to the predominant sets of forest types. In this case, the accounting does not take into account the increase in timber over time at all. The value of mature trees is reflected in the accounting only at the time of sale.

The Property Valuation Act further states that building plots of land are valued by a multiple of the land area and the price per $\mathrm{m} 2$ according to the price map of the municipality. Agricultural land is valued on the basis of rated soil ecological units. Reservoirs, streams and other land is valued in accordance with the relevant decree.

Land is also defined in International Accounting Standards in IAS 16. It is an asset that an enterprise holds because of the need to use that asset as part of a production process. The lifespan of its utility is longer than one accounting period and the entity acquires it for this purpose. It is expected that in the future, these assets will bring economic benefits to the company, including all risks and added value. It must be possible to reliably measure the acquisition costs and thus determine the acquisition price for which the land will be entered in bookkeeping. It is valued at acquisition costs, which also include acquisition-related costs (attributable). After initial recognition as an asset, the asset is accounted for at an overestimated amount, which is usually determined by reference to market price based on a qualified appraisal.

Revaluations must be performed at regular intervals. However, there is a risk that revaluation will be performed for the sake of revaluation. It would probably be more appropriate to stipulate that revaluation is necessary in significant cases and when significant values are reached. This would be specified in more detail by the entity's internal guidelines. IAS 16 states that tangible assets are plots of land, buildings and equipment held by an entity for the purpose of producing and supplying goods or services, leasing to other persons or for administrative purposes. They are expected to be used for more than one accounting period [12].

In 2018, the International Accounting Standards Board published its revised Conceptual Framework for Financial Reporting. It describes two valuation bases, namely historical costs, and present value. Historical cost reflects the price of the transaction that led to the creation of the asset. Present value then includes actual value, value from use and current costs. The conceptual framework does not favour one valuation basis over another.

In Czech accounting, land is reported and valued separately and is not depreciated in accordance with Section 28 of the Accounting Act [13]. This is a serious shortcoming, as in fact the value of the land is sometimes reduced in a permanent or temporary form (e.g. contamination due to an accident). Here, it would be appropriate to account for either allowances or accounting amortization. Due to the fact that in these cases we do not account for the decrease in the value of the land, the accounting does not show a true picture of the assets of the entity. However, if the value of the land is not actually reduced, its amortization is incorrect.

The tax regime of costs incurred to the taxpayer in connection with the acquisition, holding, appreciation and sale of land is given primarily by the fact that the land is not defined in terms of income tax as depreciated tangible assets. The tax-effective cost is generally the acquisition price of the land, at the time of sale, and in certain cases only up to the amount of income from the sale. (In the case of land acquired by a deposit, the eligible cost is determined differently, in most cases as the acquisition price registered with the depositor) [14].

Amortization is the systematic allocation of the depreciable amount of an asset over its lifespan of utility. This corrects the valuation of assets in relation to their use and the balance sheet expresses the situation of the entity more realistically [15]. 
Amortization of tangible fixed assets is an important tool when looking at a company's profit or loss. They are a part of the costs incurred [16].

An entity may choose one of the following options for amortization: even, accelerated or decelerated accounting. The chosen variant should be closest to the most faithful way of expressing the actual physical and moral wear and tear of the property [17].

Amortization puts the value of assets into costs. The total amount applied in individual years may not exceed the value expressed in the entry price, or with regard to technical evaluation [18].

In practice, there may be so-called negative technical appreciation, which will reduce the usability of assets [11].

An inventory check is necessary for the entity to determine the actual condition of the land. This is exceptional in this case in that it must take place in physical and documentary form, on the same date. The physical inventory check should find out the actual condition of the land in the field and compare it with the records in the books [19]. The revaluation of the land should take place as a result of the findings.

An important component of land is forest land. According to our legislation, in the case of a forest, the value of the land and the vegetation on it is recorded by one aggregate item and the value of these assets does not change in the accounting over the years.

Bartůn̆ková [20] states that the current methodology of accounting of forest vegetation does not provide a true picture of the company's management of the land. The shortcoming of the current Czech regulation is also the inability to record the current value of the growing stock on forest land into bookkeeping. The interested party can obtain more detailed information only in the notes to the financial statements. Conversely, International Accounting Standards separately report and measure forest land and forest vegetation, with forest vegetation being considered a biological asset until harvested. The forest vegetation must be revaluated to its current value at the time the financial statements are prepared.

Higher value of forest roads can cause positive and negative side effects [21].

The aim of the article will be achieved by a process analysis of those procedures for accounting for land, which currently apply according to Czech accounting standards. Furthermore, the results will be compared with the Accounting Act. It is obvious that Act No. 563/1991, On Accounting, contradicts itself in Section 7 paragraphs 1 and 2. It is stated here that the representation is true if the content of the items in the financial statements corresponds to the actual situation, while the representation is in accordance with the accounting methods, the use of which is imposed on the entity by this Act. In the next part, such a solution will be proposed, the result of which would be an actual depiction of reality.

\section{Materials and methods}

First, a process analysis of the current methodology of accounting for land and their valuation will be performed in accordance with the Accounting Act and Czech Accounting Standards. It will analyse the currently valid accounting procedures for accounting and valuation of land, namely Act No. 563/1991, On Accounting, Section 7, Czech Accounting Standards: No. 005 allowances, 013 tangible and intangible fixed assets, 019 costs and revenues. The method of process analysis will be used. The principles of using specific accounts and valuations in accounting for typical selected economic operations will be defined. The output will be currently valid pre-accountments.

Next, the entry price at the time of purchase will be compared with the price at the time of sale and the price development over time will be monitored. It will be determined whether there is a change in the valuation of the land due to time or temporary or permanent impairment of the land. The comparison process will take place using bookkeeping pre- 
accountments according to the valid methodology. The output will be the determination of any differences.

The next step will be the analysis of the strengths and weaknesses of accounting according to standards.

The advantages and disadvantages of the current methodological procedure for individual bookkeeping pre-accountments will be defined. The output will be an assessment of whether the current system complies with the Accounting Act and whether it is beneficial for executive decisions.

A proposal for a new methodological procedure will follow. It will include new accounting procedures, including valuations. The whole process of land revaluation will be defined with the necessary accounting documents. The output will be pre-accountments, including valuations, a list of necessary accounting documents and a proposal to change the methodology in Czech Accounting Standards. The next step will be to analyse the strengths and weaknesses of the new approach. The advantages and disadvantages of the proposed procedure will be defined here. The output will be an assessment of whether the proposed procedure is in accordance with the Accounting Act.

This will be followed by a comparison of the strengths and weaknesses of both approaches. The strengths and weaknesses of the current and proposed accounting procedures will be compared. The complexity of the application of the existing methodology in comparison with the proposed methodology will be evaluated. The output will be a comparison of the benefits of both procedures in decision-making processes.

\section{Results}

Accounting for land is the subject of Act No. 563/1991, On Accounting, and the Czech Accounting Standard for Entrepreneurs No. 013. According to these legal norms, land is a tangible fixed asset which is not depreciated. Decree No. 500/2002, which implements the Accounting Act, states that land is a tangible fixed asset, regardless of the valuation, if it is not a business commodity. It is recorded on the balance sheet asset account 031 land. Act No. 563/1991, On Accounting, states that these assets in the case of acquisition (except for own-account acquisition) are valued at acquisition cost, which is the price at which it was acquired, including acquisition-related costs.

Another option is a valuation at reproduction cost, which is the price at which it would be acquired at the time the asset is accounted for. The reproduction purchase price may also be determined by a partnership agreement or a deed of incorporation. The reproduction acquisition price is used, for example, in the case of an investment of assets in an accounting unit or if the assets are newly identified and not yet recorded in the accounts. In subsequent periods, if the land is not sold, neither the account nor the value on it changes. Only when the land is sold will the acquisition price be subtracted from account 031 and added to account 541, sold intangible and tangible fixed assets. At the same time, the revenue from this economic operation is recorded in the revenue account 641, revenue from intangible and tangible fixed assets sold and the receivable on the account 311 customers is increased. The difference between the values on accounts 541 and 641 then determines the profitability or loss.

According to currently valid standards, land is not depreciated. This follows from Section 7 of Decree No. 500/2002, Which states that accounting item land does not contain parts of the land that are depreciated, those that do are reported in construction, units of permanent crops or other tangible fixed assets. The possibility of creating accounting adjustments is neither ordered nor prohibited. However, the Czech Accounting Standard for Entrepreneurs No. 5 states that adjustments may be made to depreciated fixed assets, the value in use of 
which is normally reduced by wear and tear. It is therefore not entirely clear whether the possible creation of a provision for land would not be criticized.

It follows from the above that account 031 according to the methodology currently in force does not reflect any changes that may occur on the land itself or as a result of changes in the real estate market over time. The land is basically forever valued at the historical purchase price. This is in conflict with the Accounting Act Section 7 paragraph 2, which stipulates that the items of the financial statements should correspond to the actual situation. In reality, however, the value of land has increased over the years. There may also be, for example, contamination of the land, when, on the contrary, its value decreases temporarily or permanently, which should again be reflected in the valuation on account 031 .

The Accounting Act contradicts itself in Section 7 para. 2, where it is claimed that the presentation is true if the content of the items of the financial statements corresponds to the actual state, which is presented in accordance with accounting methods, the use of which is imposed on the entity on the basis of this of the law. The display cannot be faithful in all circumstances unless it is possible to account for an increase or decrease in the value of the land. At the same time, however, the regulations based on this Act do not allow an entity to account for this change in value.

The impossibility of accounting for an increase or decrease in the value of land is significantly reflected in the accounting for forest land. Here, the total price including the forest vegetation is accounted for on account 031 with the value of the land at the time of purchase, if this land was purchased for the purpose of further forest cultivation. In the following years, the amount of timber increases, and thus so does the actual value of the forest, but this is not reflected in the accounting at all. The price of the relevant land does not change even when the valuation regulations change. The forest vegetation will only be accounted for at the moment of harvesting, when the harvested timber is valued as a stock in account class 1 as calculated own costs and the amount is marked as an asset in account group 58 change in stock of own activities and assets. The sale of this timber is then an income for the entity in account class 6 and at the same time means an increase in receivables from customers. Account 031 land remains valued at the original historical price at all times.

It is therefore clear that the methodology of accounting and valuation of land is not comprehensively resolved in the Czech Republic and that in practice a number of situations may arise that no existing legal norm addresses. However, this is a serious shortcoming, because in real life there is a real change in the price of land almost constantly. Land owned by an entity may represent a significant value item in its balance sheet. However, shareholders or other stakeholders will not find out, as they only have a historical price at a value that is far from reflecting the current price of the land. The only possible solution at present is to state the current market price of the land in the notes to the financial statements, but the question is whether the authors of the notes do so.

Pre-accountment for selected accounting transactions is shown in the table 1.

Table 1. Accounting for land according to regulations valid in the Czech Republic

\begin{tabular}{|c|c|}
\hline Economic operation & Pre-accountment - valuation \\
\hline Purchase of land from a supplier & $\begin{array}{l}031 / 321 \text { - purchase price - acquisition } \\
\text { price }\end{array}$ \\
\hline $\begin{array}{l}\text { Deposit of land into company ownership } \\
\text { by an individual entrepreneur }\end{array}$ & $\begin{array}{l}031 / 491 \text { - price determined by an expert - } \\
\text { acquisition price }\end{array}$ \\
\hline $\begin{array}{l}\text { Sale of land - decommissioning from } \\
\text { bookkeeping }\end{array}$ & 541/031 - acquisition price \\
\hline Accountment of revenue for sold land & $311 / 641$ - sale price - market price \\
\hline
\end{tabular}




\begin{tabular}{|l|l|}
\hline $\begin{array}{l}\text { Activation of wood mass in the forest after } \\
\text { its extraction }\end{array}$ & $1 \mathrm{xx} / 58 \mathrm{x}-$ calculated own costs \\
\hline Issuance of an invoice for the sale of timber & $311 / 601$ - market price \\
\hline
\end{tabular}

Source: Own processing.

From the above overview, it is clear that account 031 land is constantly working with the acquisition price, which never changes and does not respond to changes in the quality of land or market developments.

The advantages of the current land accounting system are low labour and time costs and financial simplicity. It is not necessary to seek expert valuation.

The disadvantage of the current method of accounting for land is the fact that accounting does not provide true information about the current state of these assets, which does not fulfil one of the basic functions of accounting. Distorted information can be misleading to shareholders and the market.

The current situation could be changed by an amendment to the accounting rules in the area of land. Land revaluation would not have to take place on an annual basis for each entity, but the obligation to do so could be required by the entity's internal guidelines. The revaluation should take place no more than once a year as at the date of the annual accounts, based on the findings of taking inventory. The inventory committee should assess the condition of the relevant land and propose a revaluation if a fundamental change compared to the previous accounting period is found.

In the event that a decrease in the value of the land is detected during the accounting period, e.g. by contamination in the event of an ecological accident, an expert valuation should be prepared. It should determine whether it is possible to restore the land to its original condition or not. Furthermore, the current value of the land should be determined in it.

If it were stated in the expert opinion that the land can be restored to its original condition after the relevant measures have been taken, it would be possible to account for provisions in the account in group 55 creation and settlement of adjustments in the operating area in relation to the account in group 09 adjustment items of fixed assets. After the land has been restored to its original condition, the adjustment would be cancelled in its entirety.

If for some reason it was not possible to restore the land to its original condition, then its value would have to be reduced to the appropriate extent by depreciation, using account 549 deficit, damages and extraordinary operating costs and reducing the value on account 031 land. However, some value would always remain on account 031 . In an extreme situation, for example, if an entity owns land on a riverbank and during a flood this part is completely washed away, then account 031 land would be cancelled completely.

However, these accounting operations would always have to be performed on the basis of an expert opinion or a document from the cadastral office. These documents would also be considered accounting documents.

The opposite is the increase in the value of the land. This may be due to price movements in the real estate market, landscaping, etc.

In terms of market influence, an increase in the accounting value of the land would be recognized only for the annual balance sheet date if the increase in the market price would be significant. This issue would be more precisely defined by the company's internal guidelines. The increase would concern account 031 land and the corresponding account change in balance. This is currently posted in account group 58, which is not ideal. The former method of accounting for changes in revenue was more appropriate, but the current rules must be respected.

In the event that the land value increases for another reason, e.g. due to landscaping, then the balance of account 031 land would increase again and the account 321 suppliers would be used in the case of the purchase of this activity. If the entity carried out this activity itself, 
then it would use the account in group 58. The basis for accounting would be an expert opinion, which would be an accounting document.

In my opinion, accounting for forest vegetation is completely incorrect. A distinction should be made between the value of land itself and the value of forest vegetation, e.g. by analytics to account 031 land. When buying land, the expert should already distinguish these two components in his opinion.

Wood mass grows every year and on the basis of an expert opinion, its current value should be determined at specified intervals. An increase would then be charged to the relevant analytical account 031 land in relation to the account in group 58 change in balance. In the case of logging or destruction by storms, bark beetles, etc., the relevant analytical account 031 of land would be reduced in relation to the cost account in group 58 change of state or 549 deficit, damages and extraordinary events. When selling wood, the account 311 customers would be used in conjunction with the revenue account 601 sales of own products. The condition of the forest after a storm or bark beetle infestation would again have to be assessed by an expert in his opinion.

In my opinion, these proposed procedures would respect the Accounting Act, which mandates a true and fair view of the real situation. Executives, shareholders and the market would obtain accurate and up-to-date information about the entity and its components of assets. On the other hand, it would be much more time and money consuming to obtain accounting documents.

The table 2 contains a proposal for accounting pre-accountment of selected economic operations.

Table 2. Proposed pre-accountments

\begin{tabular}{|l|l|}
\hline \multicolumn{1}{|c|}{ Economic operation } & \multicolumn{1}{|c|}{ Pre-accountment - valuation } \\
\hline Creation of an adjustment for land & $55 \mathrm{x} / 09 \mathrm{x}$ - value determined by an expert \\
\hline $\begin{array}{l}\text { Decrease in the value of the land due to } \\
\text { irreparable damage }\end{array}$ & $\begin{array}{l}549 / 031 \text { - value determined by an expert, or } \\
\text { the acquisition price }\end{array}$ \\
\hline $\begin{array}{l}\text { Revaluation of land due to a significant } \\
\text { change in market price }\end{array}$ & $031 / 58 \mathrm{x}$ - value determined by an expert \\
\hline $\begin{array}{l}\text { Land value increase due to landscaping - by } \\
\text { supplier }\end{array}$ & $031 / 321$ - invoiced price \\
\hline $\begin{array}{l}\text { Land value increase due to landscaping - in- } \\
\text { house }\end{array}$ & $031 / 58 \mathrm{x}$ - value determined by an expert \\
\hline $\begin{array}{l}\text { Purchase of forest - the division of the price } \\
\text { into land and timber }\end{array}$ & $\begin{array}{l}031 / 1 / 2 \mathrm{AE} / 321 \text { - invoiced price including } \\
\text { expert opinion }\end{array}$ \\
\hline Growth of wood in the forest & $031 \mathrm{AE} / 58 \mathrm{x}$ - value determined by an expert \\
\hline $\begin{array}{l}\text { Logging - reducing the value of forest } \\
\text { property }\end{array}$ & $58 \mathrm{x} / 031 \mathrm{AE}$ - calculated price \\
\hline $\begin{array}{l}\text { Destruction of forest vegetation due to } \\
\text { natural disaster }\end{array}$ & $\begin{array}{l}549 / 031 \text { AE - value determined by an } \\
\text { expert }\end{array}$ \\
\hline Sale of wood - issued invoice & $311 / 601$ - invoiced price \\
\hline
\end{tabular}

Source: Own processing.

When applying the proposed accounting procedures, it will be necessary to often use the services of experts, where their opinion would also fulfil the function of an accounting 
document. It would have to contain all the requisites arising from Section 11 of the Accounting Act and it would also have to be kept properly.

The newly proposed accounting procedures are in accordance with the Accounting Act, but in conflict with Czech Accounting Standards. However, as mentioned above, this follows from the fact that these standards themselves are in conflict with the Accounting Act in this area.

The advantage of the newly proposed methodological procedures is a realistic view of the entity's assets, where managers, owners and the market obtain true information about the current value of land owned by the entity.

The disadvantage is higher labour, the need for more frequent monitoring of the development of land prices on the market and the condition of the land. A significant negative can be the need to use the services of experts often, the cost of preparing an opinion and the simple fact that there are a limited number of such experts.

If the current and newly proposed procedure of accounting and valuation of land is compared, we will find that the procedures still in force are not laborious and do not require the provision of additional documents over time. However, the information we obtain from accounting is becoming less and less relevant over time.

The proposed procedure is significantly more time-consuming and labour-intensive than the application of the current methodology and the entity will undoubtedly incur costs in seeking up-to-date expert opinions, and it may be a problem to obtain an expert. It will also be necessary to ensure that any revaluation of land does not lead to malpractice.

The advantage of the proposed methodology is to achieve a state where the accounting will actually show the current situation of the accounting entity, the assets will be recorded at fair value and thus the managers of the entity, owners and the market will obtain true information.

It should also be noted that the proposed change in the accounting and valuation of land is not systemic in relation to the accounting for other tangible fixed assets. However, this is justified by the fact that these are special, non-depreciable assets. This is more or less the same problem as in the case of accounting for works of art and collections (Table 3).

Table 3. Comparison of the current and proposed states

\begin{tabular}{|l|l|}
\hline \multicolumn{1}{|c|}{ Current methodology } & \multicolumn{1}{c|}{ Proposed methodology } \\
\hline $\begin{array}{l}\text { Not in accordance with the Accounting Act, } \\
\text { it is in accordance with Czech Accounting } \\
\text { Standards }\end{array}$ & $\begin{array}{l}\text { In accordance with the Accounting Act, but } \\
\text { conflict with Czech Accounting Standards }\end{array}$ \\
\hline $\begin{array}{l}\text { Over time, the unrealistic value of the land } \\
\text { can negatively affect decision-making }\end{array}$ & $\begin{array}{l}\text { Over time, the value of the land is updated } \\
\text { according to its actual condition and market }\end{array}$ \\
\hline $\begin{array}{l}\text { Low workload, it is not necessary to obtain } \\
\text { new expert opinions and spend funds on } \\
\text { their processing }\end{array}$ & $\begin{array}{l}\text { Significantly labourious, the need to } \\
\text { provide an expert who prepares the report, } \\
\text { higher costs }\end{array}$ \\
\hline $\begin{array}{l}\text { The data obtained from the accounts over } \\
\text { time are not in line with reality }\end{array}$ & $\begin{array}{l}\text { The data obtained from the accounts are in } \\
\text { line with reality }\end{array}$ \\
\hline
\end{tabular}

Source: Own processing.

\section{Discussion}

The first research question was whether the current procedure of accounting for land according to Czech Accounting Standards is in accordance with the Accounting Act. 
It is found that Czech accounting standards in this area are in conflict with Act No. 563/1991, On Accounting. In Section 7 paragraphs (1) and (2), it requires entities to keep accounts in such a way that the financial statements prepared on its basis give a true and fair view of the subject matter and financial position of the entity. According to this Act, the display is true if the content of the items in the financial statements corresponds to the actual situation.

Czech Accounting Standard No. 13 for Entrepreneurs states in Part 4 that tangible fixed assets are depreciated in accordance with Section 56 of Decree No. 500/2002. However, according to this standard, land is not depreciated, so that in accounting practice it is not possible to document a decrease in the value of land in any way.

Nor is it possible to account for the increase in the value of the land, which undoubtedly actually happens very often. Section 27 of the Accounting Act defines the assets that can be measured at fair value, but land is not listed here. Section 25 of this Act orders the valuation of acquired tangible fixed assets at acquisition cost. It follows that the purchased land will be valued once and for all at the acquisition price, regardless of any devaluation of the land in the future or the growth of its value due to market influence. In the case of land with mature forest vegetation, the price recorded in the accounts and the market price are completely different and the condition of the land itself and the condition of the forest vegetation is not reflected at all. The information about the forest is, in fact, untrue and misleading from the very beginning, as the value of the land itself and the value of the vegetation growing on it are not separated at all.

It must therefore be stated that the rules of law governing land accounting are contradictory and, as a result, accounting in this area does not give a true and fair view of that component of assets.

The answer to the first question must therefore be that Czech accounting standards in the area of land accounting are in complete conflict with the Accounting Act.

The second research question asked whether there is a method of accounting for land that corresponds to the principle of actual representation of reality.

The answer to the second question is that according to the valid Czech legislation, it is currently not possible to account for land so that the accounting gives a true and fair view of the facts.

Possible accounting procedures, which would result in a realistic presentation of the facts, are suggested in the previous part of the article. However, a prerequisite for their application in practice is a significant amendment to Czech Accounting Standards and Decree No. $500 / 2002$.

Legal norms in this area are from earlier times when land prices were not very high. However, land prices are rising, as citizens and businesses consider buying land as a certain investment. It is also necessary to take into account the fact that the amount of land is limited.

\section{Conclusions}

The aim of the paper is to analyse the accounting procedures for accounting for land according to applicable Czech legislation and to propose a new methodology.

It was found that Czech accounting standards in the area of land accounting are in conflict with the Accounting Act. This Act is then in conflict with Decree No. 500/2002.

Land is recorded in the accounting at acquisition price and does not reflect any decrease or increase in the value of the land. In the case of a forest, the accounting procedures are erroneous and insufficient from the very beginning, as the condition of the land itself and the condition of the vegetation growing on it are not taken into account at all. The accounting does not show an increase in the value of the forest due to the increase in timber. 
The current accounting procedures for accounting and valuation of land are in all respects undemanding, the entity does not have to obtain new expert opinions on an ongoing basis or spend additional funds to pay for these expert opinions. However, the information provided in the accounts is becoming less and less up-to-date over time.

Managers, shareholders, and the market currently obtain completely outdated or untrue information from accounting data in this area, which can be the cause of fatal decisions.

The article proposes new procedures for land accounting. According to them, it would be possible to account for a permanent and temporary decrease in the value of land as well as for an increase in the value of land, which occurs mainly due to rising land prices. A procedure for accounting for forest land was also proposed, which would use analytical accounts to separate the value of the land itself and the value of the vegetation. Then it would be possible to account for an increase in the value of the forest itself due to the increase in wood mass.

The newly proposed procedures would be much more laborious and costly for the entity, as it would be necessary to regularly assess the current price of the land and provide expert services.

The application of the proposed procedures would comply with the requirements of the Accounting Act and would provide true and up-to-date information on the value of these assets, which would be beneficial for users of the information. The aim of the paper was therefore achieved.

The newly proposed procedures deviate from the currently valid system of accounting for tangible fixed assets, which is forever (with the exception of technical improvement) recorded at acquisition price, while its residual accounting value is updated through accounting amortization. However, land is such a specific type of property that this exception can be justified.

According to the Czech methodology, it is not possible to account for land in any other way than stated above. Undoubtedly, it would be interesting to compare these accounting practices with International Accounting Standards. This comparison will be the content of the next article.

\section{References}

1. J. Kouřilová, K vývoji a pojetí účetnictví, vnímání předmětu [The development and concepts of accounting, the perception of the subject]. Ekonomické dopady legislativnich změn v oblasti financí, účetnictví a daní (2. dil) [Economic Impacts of Legislative Changes in Finance, Accounting and Taxes (Part 2)], (2015)

2. V. Mykolaiotiene, G. Vecerskiene, K. Jankauskine, L. Valanciene, Peculiarities of tangible fixed assets accounting. Inzinerine Ekonomika - Engineering Economics, 21(2), 142-150 (2010)

3. B. Sabuncu, Measurement and accounting of tangible fixed assets in terms of the finantial reporting standard for large and medium sized enterprises. Journal of Economics and Administrative Sciences, 14(3), 713-727 (2019)

4. M. Pekárek, J. Dudová, J. Hanák, I. Průchová, J. Tkáčiková, Pozemkové právo [Land Law]. Brno: Masaryk University Brno (2003)

5. J. J. Weygandt, P. D. Kimmel, D. E. Kriso, Acounting principles: International student version. $11^{\text {th }}$ ed. Hoboken: Wiley (2014)

6. U. Ozdilek, Land and building separation based on Shapley values. Palgrame Communications, 6(1), Art. No.: 68 (2020) 
7. R. Zdenek, J. Lososová, Investments of Czech farms located in less favoured areas after EU accesion. Agricultural Economics - Zemédělská ekonomika, 66(2), 55-64 (2020)

8. D. Geltner, A. Kumar, A. M. Van de Minne, Riskiness of real esstate development: A perspektive from urban economics and opticon value theory. Real Estate Economics. 48(2), 406-445 (2020)

9. P. Ort, Oceňování nemovitostí - moderní metody a prístupy [Real estate valuation modern methods and approaches]. Prague: Leges. 32-37 (2013)

10. J. Sedláček, Základy finančního účetnictví [Basics of financial accounting]. Prague: Ekopress (2005)

11. M. Skála, Technické zhodnocení a opravy [Technical evaluation and repairs]. Ostrava: Sagit (2008)

12. M. I. Wiecenk, M. N. Joung, IFRS Primer International Gaap Basics. The United States of America: George Hoffman (2009)

13. P. Ryneš, Podvojné účetnictví a účetní závěrka 2020 [Double entry accounting and financial statements 2020]. Olomouc: Anag (2020)

14. J. Nigrin, Pozemky v daňových nákladech [Land in tax costs]. Verlag Dashofer (2016)

15. J. Strouhal, Lexikon účetnich pojmů [Lexicon of accounting terms]. Prague: Wolters Kluwer (2015)

16. A. Suhanyiova, L. Suhanyi, Analysis of depreciation of intangible and tangible fixed assets and the impact of depreciation on the profit or loss and the tax base of the enterprise. 18th International Scientific Conference on International Relations. Current Issues of World Economy and Politics, 939-950 (2017)

17. P. Valouch, Účetní a daňové odpisy [Accounting and tax depreciation]. Prague: Grada Publishing (2012)

18. P. Prudký, M. Lošták, Hmotný a nehmotný majetek v praxi: komentářr, př́klady, výklad změn [Tangible and intangible assets in practice: commentary, examples, interpretation of changes]. Olomouc: Anag (1997)

19. J. Svobodová, Inventarizace - praktický průvodce [Inventory - a practical guide]. Olomouc: Anag (2013)

20. L. Bartůn̆ková, Účetní systém vybraného lesnického podniku [Accounting system of chosen forestry company]. Brno: Mendel University in Brno, diploma thesis (2010)

21. P. Toscani, W. Sekot, F. Holzleitner, Forest road from the perspective of managerial accounting - Empirical evidence from Austria. Forests, 11(4), Art. No.: 378 (2020) 